\title{
Survival and Side Effects of Cisplatin/Cyclophosphamide and Carboplatin/Paclitaxel Adjuvant Chemotherapy in Stage IC-IV Ovarian Cancer
}

\author{
Kesintasan dan Efek Samping Kemoterapi Adjuvan Cisplatin/Cyclosphosphamide \\ dan Carboplatin/Paclitaxel pada Kanker Ovarium Stadium IC-IV
}

\author{
Unedo H Markus' ${ }^{1}$, Hariyono Winarto', Andrijono', Bambang Sutrisna ${ }^{2}$ \\ ${ }^{1}$ Gynecologic Oncology Division \\ Obstetrics and Gynecology Department \\ Faculty of Medicine, University of Indonesia \\ ${ }^{2}$ Epidemiology Department \\ Faculty of Public Health, University of Indonesia
}

Jakarta

\begin{abstract}
Objective: To compare the survival and side effects in epithelial ovarian cancer patients receiving adjuvant chemotherapy of cisplatin/cyclophosphamide and carboplatin/paclitaxel.

Method: We recruited epithelial ovarian cancer patients receiving cisplatin/cyclophosphamide (group A) or carboplatin/paclitaxel (group B) adjuvant chemotherapy after surgery. Chemotherapy was given for six cycles. Overall survival and side effects were assessed.

Result: A total of 49 patients were recruited, consisting of 25 patients for group A and 24 patients for group B. In this study, the overall survival of stage IC-IV ovarian cancer patients was 37.3 months in group A $(95 \% \mathrm{CI}=31.86-43.46)$ and 35.5 months $(95 \% \mathrm{CI}=13.93$ $43.46)$ in group $B(p<0.001)$. Hematologic side effects of both groups were not significantly different, i.e: leukopenia $12 \%$ vs $18 \%(p=0.14)$ and thrombocytopenia $5.3 \%$ vs $9.7 \%(p=0.38)$ in group $A$ and group $B$, respectively. Gastrointestinal toxicity occurred more frequently in group A, i.e: nausea $38.6 \%$ vs $22.9 \%(\mathrm{p}<0.05)$, vomitus $24.6 \%$ vs $11.8 \%(\mathrm{p}<0.05)$ in group A and group B, respectively. Symptoms of peripheral sensory neuropathy were found in $5.33 \%$ of group A subjects and $23.6 \%$ of group B $(\mathrm{p}<0.05)$.

Conclusion: Overall survival in this study is better in patients receiving cisplatin/cyclophosphamide than patients receiving carboplatin/paclitaxel. However, further study with larger sample is still needed. The gastrointestinal side effects are found more frequently in the cisplatin/cyclophosphamide group, while peripheral sensory neuropathy and hematologic side effects are more frequent in the carboplatin/paclitaxel group.
\end{abstract}

[Indones J Obstet Gynecol 2015; 2: 110-116]

Keywords: carboplatin/paclitaxel, cisplatin/cyclophosphamide, ovarian cancer, overall survival, side effects

\begin{abstract}
Abstrak
Tujuan: Membandingkan kesintasan dan efek samping antara pasien kanker ovarium tipe epitelial yang menerima kombinasi kemoterapi cisplatin/cyclosphosphamide dengan carboplatin/paclitaxel.

Metode: Pasien kanker ovarium epitelial mendapat ajuvan kemoterapi dibagi menjadi dua kelompok berdasarkan jenis obat yang diterima; kelompok A yaitu kelompok yang menerima cisplatin/cyclophosphamide, dan kelompok B yaitu kelompok yang menerima carboplatin/paclitaxel. Kemoterapi diberikan sebanyak enam siklus. Dilakukan penilaian kesintasan dan efek samping masing-masing kelompok.

Hasil: Terdapat 49 pasien dalam penelitian ini, terdiri dari 25 pasien dalam kelompok A dan 24 pasien dalam kelompok B. Kesintasan keseluruhan kanker ovarium stadium IC-IV pada kelompok A yakni 37,3 (IK95\%=31,86-43,46) bulan, sedangkan kelompok B yakni 35,5 (IK95\%=13,93-43,46) bulan ( $(<<0,001)$. Efek samping hematologi tidak berbeda secara signifikan, di mana pada kelompok A didapatkan leukopenia sebanyak $18 \%$ dan trombositopenia $9,7 \%$, sedangkan pada kelompok B sebanyak 12\% dan 5,3\% ( $p=0,14$ dan 0,38). Toksisitas gastrointestinal lebih sering terjadi pada kelompok A, di mana didapatkan keluhan mual sebanyak 38,6\% dan muntah sebanyak 5,33\%, sedangkan pada kelompok B sebanyak 22,9\% dan 11,8\% (p<0,05). Gejala neuropati perifer lebih sering pada kelompok $B$, yakni sebanyak 23,6\% dibandingkan pada kelompok A, yakni 5,33\% $(p<0,05)$.

Kesimpulan: Kesintasan keseluruhan secara signifikan lebih baik pada kelompok cisplatin/cyclophosphamide dibandingkan kelompok carboplatin/paclitaxel. Namun, diperlukan studi lebih lanjut dengan sampel yang lebih besar. Efek samping sistem gastrointestinal lebih sering terjadi pada kelompok cisplatin/cyclophosphamide, sedangkan sistem hematologi dan saraf lebih sering terjadi pada kelompok carboplatin/paclitaxel.
\end{abstract}

[Maj Obstet Ginekol Indones 2015; 2: 110-116]

Kata kunci: carboplatin/paclitaxel, cisplatin/cyclosphosphamide, efek samping, kanker ovarium, kesintasan keseluruhan

Correspondence: Unedo H Markus. Department of Obstetrics and Gynecology, Faculty of Medicine University of Indonesia, Jakarta Telephone: 08122637874, Email:unedoedo@yahoo.com

\section{INTRODUCTION}

Ovarian cancer is the seventh most common female cancer worldwide in 2012. ${ }^{1}$ Each year,
22,280 new cases are diagnosed, leading to 15,500 deaths. ${ }^{2}$ This cancer is the leading cause of death among gynecological cancers. There is usually no 
symptom in the early stages, and most of the time symptoms present in an advanced stage. More than $75 \%$ of patients present with advanced stage or stage III-IV according to the International Federation of Gynecology and Obstetrics (FIGO) classification. ${ }^{3-6}$ In Indonesia, according to the Indonesian Society of Gynecologic Oncology (INASGO), the incidence of ovarian cancer was 363 cases in 2013. ${ }^{7}$

More than three decades ago, the standard adjuvant chemotherapy treatment of ovarian cancer in the United States was cisplatin/cyclosphosphamide (CC). McGuire et al, held a randomized study in the Gynecologic Oncology Group (GOG) 111 comparing the use of CC and carboplatin/paclitaxel (CP). The progression-free survival was significantly longer $(\mathrm{p}<0.001)$ in the CP group compared to the CC group (median 18 vs 13 months). Overall survival was also longer $(\mathrm{p}<0.001)$ in the CP group than in the CC group (median 38 vs 24 months). ${ }^{8}$

Chemotherapy has numerous known side effects, including bone marrow suppression, liver disorders, GI tract disorders, renal toxicity, neurotoxicity and ototoxicity. Cisplatin generally has more side effects compared to carboplatin, except in terms of hematologic effects, especially granulocytopenia and thrombocytopenia. Currently, carboplatin and paclitaxel is used as the standard adjuvant chemotherapy that shows good effectivity and less side effects, although they are quite expensive compared to the older regimen of cisplatin and cyclophosphamide.

Therapy for epithelial ovarian cancer according to INASGO guidelines, consists of administration of $50-100 \mathrm{mg} / \mathrm{m}^{2}$ cisplatin or AUC 5-6 carboplatin, combined with $600 \mathrm{mg} / \mathrm{m}^{2}$ cyclosphosphamide or $175 \mathrm{mg} / \mathrm{m}^{2}$ paclitaxel. ${ }^{9}$

In Indonesia there is no data on the survival and side effects of different regimens of chemotherapy in patients with advanced ovarian cancer. The aim of this study is to compare the overall survival and side effects of cisplatin/cyclophosphamide and carboplatin/paclitaxel chemotherapy regimens.

\section{METHODS}

This historical cohort study's target population were patients with stage IC-IV epithelial ovarian cancer who presented to Dr. Cipto Mangunkusumo Hospital gynecologic oncology clinic, from January $1^{\text {st }} 2008$ to December $1^{\text {st }} 2013$.
We included all patients with stage IC-IV ovarian cancer patients who have undergone surgery and received adjuvant chemotherapy of cisplatin and cyclophosphamide or carboplatin and paclitaxel, had a performance status score $\leq 2$ based on the Eastern Cooperative Oncology Group (ECOG) criteria, and whose laboratory results were within normal limits. Patients were excluded if they received fewer than 6 cycles of chemotherapy, or had abnormal laboratory results prior to chemotherapy.

Patients who met the criteria were examined clinically and using ultrasound (Accuvix ${ }^{\circledR} \mathrm{XQ}$, Medison, Seoul, Korea). Some were also selectively examined using CT Scan and MRI before undergoing debulking laparotomy or surgical staging. Chemotherapy were given intravenously for at least $6 \mathrm{cy}$ cles. The dose of cisplatin was $50 \mathrm{mg} / \mathrm{m}^{2}$ in combination with $600 \mathrm{mg} / \mathrm{m}^{2}$ cyclophosphamide. Carboplatin dose was $300 \mathrm{mg} / \mathrm{m}^{2}$ or AUC 6 , combined with $175 \mathrm{mg} / \mathrm{m}^{2}$ paclitaxel. Progression-free and overall survival were assessed after 6 cycles of chemotherapy by referring to patients' medical records, direct interviews, and phone call interviews. Adverse effects were assessed after each cycle using the National Cancer Institute (NCI) Common Toxicity Criteria version 1 . The data were statistically analyzed using Stata version 12 program (Stata Corp. LP, Texas, USA).

\section{RESULTS}

The number of epithelial ovarian cancer patients who met the inclusion and exclusion criteria was 70 patients. The subjects were then divided into 2 groups, group A comprised of 35 (43.21\%) cases treated with cisplatin/cyclosphosphamide, and group B comprised of 46 (56.79\%) cases treated with carboplatin/paclitaxel chemotherapy regimen. At the end of the study, 21 patients were dropped out of the study, because they did not finish six cycles of chemotherapy. Therefore, 25 patients $(71.43 \%)$ in group A and 24 patients $(53.17 \%)$ in group B were accounted for analysis,

The patients recruited in this study have a tendency for equally distributed characteristics between the two groups. The costs per cycle of chemotherapy in both groups were expectedly different. The cost of one cycle in group A was a lot cheaper compared to the cost in group $B$. 


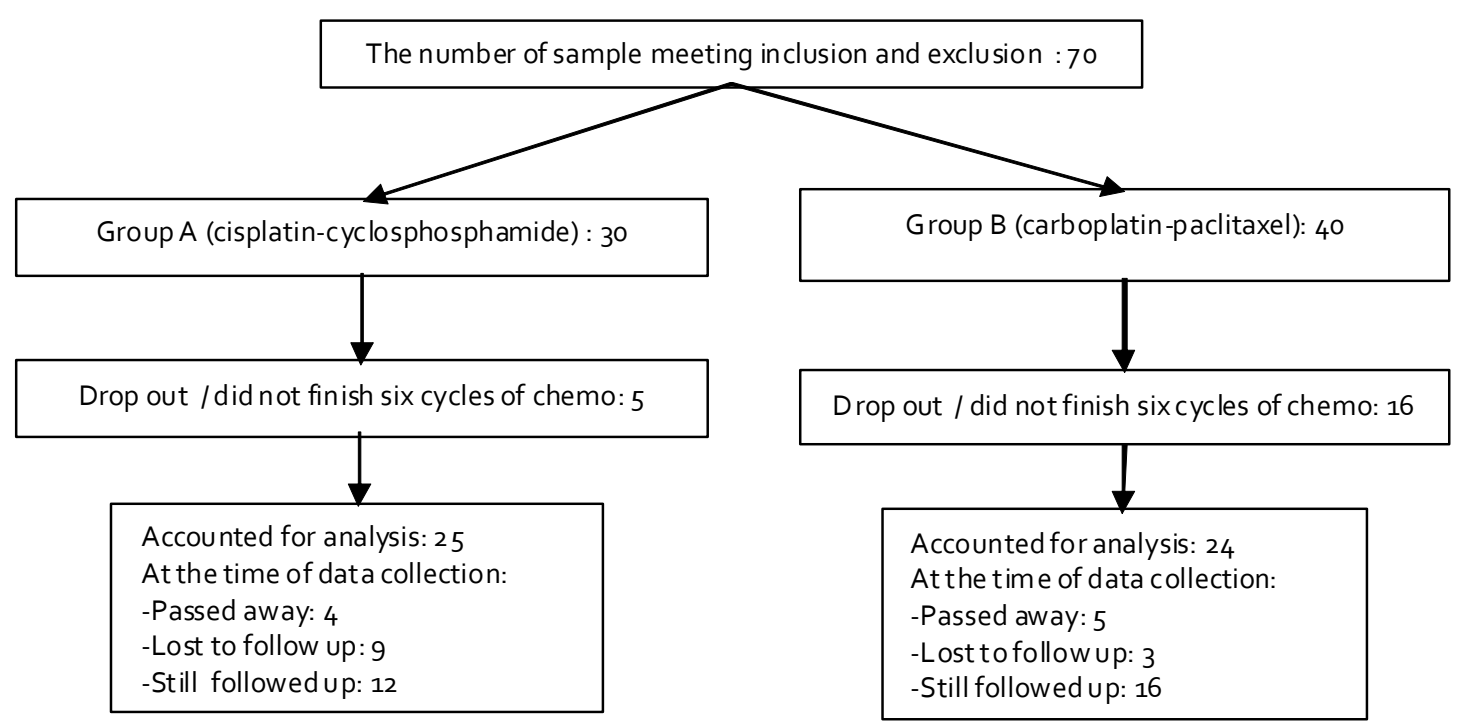

Figure 1. Sample Group Based on Chemotherapy Regimen and the Last Condition of the Patient.

Kaplan-Meier curve in Figure 2 shows both groups' survival curves. There was a significant difference between the two groups' overall survival. Overall survival of stage IC-IV ovarian cancer patients was 37.3 months in group A $(95 \% \mathrm{CI}=31.86$ 43.46) and 35.5 months (95\% CI=13.93-43.46) in group B $(\mathrm{p}<0.001)$, as portrayed in Table 2 .

Assessment of side effects was done based on the examination table from the NCI Common Toxicity Criteria Version 1. Assessment after each cycle is presented in Table 3.

Assessment of hematologic side effects includes hemoglobin, leukocyte, and thrombocyte counts. There were no significant differences in hematologic parameters between both groups. Statistically significant differences were found in gastrointestinal side effects. Patients in group A experienced significantly more nausea and vomiting in comparison to those in group B. However, there was no significant difference in terms of diarrhea and stomatitis between both groups. In the assessment of CNS side effects, group A reported significantly more headache than group B, but group B reported more peripheral neuropathy.

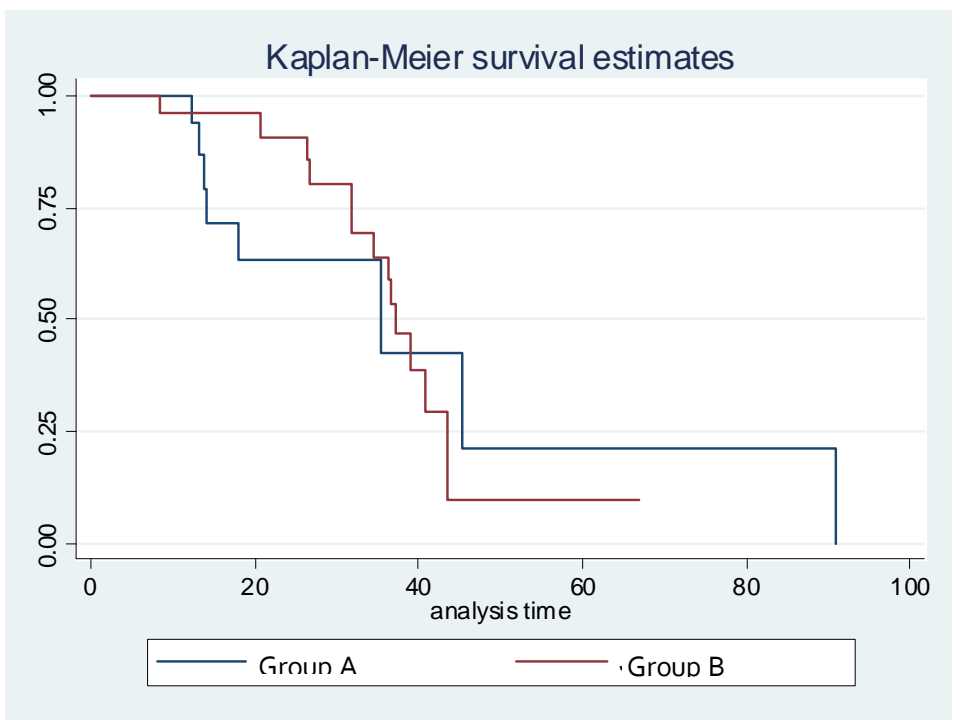

Figure 2. Overall survival of group A (cisplatin/cyclosphosphamide) and group B (carboplatin/paclitaxel). 
Table 1. General Characteristics of Patients According to the Chemotherapy Treatment.

\begin{tabular}{cccc}
\hline \multicolumn{1}{c}{ Characteristics } & Group A n(\%) & Group B n(\%) & p-value \\
\hline $\begin{array}{c}\text { Age in years (med, min-max) } \\
\text { Parity }\end{array}$ & $44(30-61)$ & $52.5(44-78)$ & $0.0003^{*}$ \\
0 & $7(28)$ & & \\
1 & $6(24)$ & $5(25)$ & \\
$\geq 2$ & $12(48)$ & $13(54.17)$ &
\end{tabular}

Chief complaint

No complaints

Abdominal lump

Abdominal pain

Dyspnea

Performance status

$$
0
$$

1

2

Histopathology

Serous

Musinosus

Clear cell

Endometrioid

Tumor grade

Well-differentiated
Moderate
Undifferentiated

Stage$$
\text { IC }
$$

II

III

IV

Stage

Early

Advanced

Time of administration

\begin{tabular}{cccc} 
Neoadjuvant & $5(20)$ & $4(16.7)$ & 0.763 \\
Adjuvant & $20(80)$ & $20(83.3)$ & \\
Cost per cycle (IDR) & 838.787 & 5.532 .137 & $<0.001^{*}$ \\
\hline${ }^{*}$-value $<0.05$ & &
\end{tabular}

$1(4) \quad 0(0)$

$21(84) \quad 18(75)$

$1(4) \quad 5(20.83)$

$2(8) \quad 1(4.17)$

0.781

$15(60) \quad 20(83.3)$

$4(16) \quad 2(8.3)$

0.186

$2(8.3)$

10 (41.7)

$1(4,2)$

10 (41.7)

0.484

7 (28)

3 (12.5)

13 (28.26)

7 (23.33)

18 (39.13)

11 (36.67)

0.490

$12(40)$

4 (16.7)

4 (16.7)

$13(54.7)$

0.458

3 (12.5)

$4(16)$

8 (33.3)

0.686

16 (66.7)

$21(84)$

(18)

(16.7)

${ }^{*} p$-value $<0.05$

Table 2. Median of Overall Survival in Both Groups.

\begin{tabular}{lccc}
\hline \hline & $\begin{array}{c}\text { Group A } \\
\text { Cisplatin- Cyclosphosphamide }\end{array}$ & $\begin{array}{c}\text { Group B } \\
\text { Carboplatin-Paclitaxel }\end{array}$ & p-value \\
\hline Median of Overall Survival (month) & 37.3 & 35.5 & $<0.001$ \\
$95 \% \mathrm{CI}$ & $31.86-43.46$ & $13.93-43.46$ & \\
\hline \hline
\end{tabular}




\section{DISCUSSION}

A study conducted by McGuire et $\mathrm{al}^{8}$ found significantly higher survival rate in ovarian cancer patients receiving $\mathrm{CP}$ chemotherapy than those receiving CC; 38 months (95\%CI=32-44) vs 24 months $(95 \% \mathrm{CI}=21-30)$. Piccart et $\mathrm{al}^{10}$ also found that patients receiving $\mathrm{CP}$ had better survival compared to those receiving $\mathrm{CC}$, where the survival was 35.6 and 25.8 months, respectively. Meanwhile, our results were contradictory to results of these previous studies, where our patients who received CC had a significantly longer overall survival. It suggests that in our sample, a combination of platinum-based therapy with cyclophosphamide is better than with taxanes.

However, it is too early to conclude that cyclophosphamide is better than taxanes in combination with platinum-based chemotherapy for survival. Our results could be by the lack of homogeneity in our patients. The patients in group B was relatively older than group A. The study counducted by Ries et $\mathrm{al}^{11}$ discovered that the older the age of ovarian cancer patients, the worse the prognosis or survival. Moreover, the number of patients recruited in this study was too small, with about a third of the patients having to be excluded.

McGuire et $\mathrm{al}^{8}$ observed that the $1^{\text {st }}, 2^{\text {nd }}, 3^{\text {rd }}$, and $4^{\text {th }}$ degree reduction of leukocytes/neutrophil appeared in $4 \%, 9 \%, 22 \%$, and $61 \%$ of patients in the CC group, while in the CP group they appeared in $2 \%, 4 \%, 14 \%$, and $78 \%$ of patients, respectively. Although neutropenia of grade 3 or 4 developed in the majority of women in the CP group, the incidence of febrile neutropenia was low and was consistent with the brevity of paclitaxel-induced myelosuppression. As for gastrointestinal symptoms, the occurrence of toxicity according to severity ( $11^{\text {st }}$ $4^{\text {th }}$ degree) was $8 \%, 42 \%, 8 \%$, and $3 \%$ in the group receiving cyclophosphamide, and 14\%, 42\%, 12\%, and $3 \%$ in those receiving taxanes.

Piccart et al ${ }^{10}$ found in his research that $31 \%$ of subjects in the CC group developed $3^{\text {rd }}$ grade neutropenia and $40 \%$ of them developed $4^{\text {th }}$ grade neutropenia. In the CP group, $3^{\text {rd }}$ and $4^{\text {th }}$ grade neutropenia were experienced by $32 \%$ of subjects each. Severe nausea was more often experienced by those in the CC group. Meanwhile, neurosensory symptoms appeared more frequently in CP group.
In our study, neutropenia was found in $12 \%$ of patients in group A and 18\% of patients in group B. Nausea was more commonly encountered in group A in comparison to group B. Vomiting was found up to three times more frequently in group A than in group B. Furthermore, we found the prevalence of neurosensory disturbance to be $5.3 \%$ in group $A$, and $23.6 \%$ in group $B(p<0.05)$. These results show that compared to $\mathrm{CC}$ combination, $\mathrm{CP}$ combination causes less gastrointestinal side effects but more hematologic and neurologic side effects. No apparent allergic reaction was observed in both group A and group B.

\section{CONCLUSION}

Overall survival of ovarian cancer patients in this study is better in patients receiving cisplatincyclophosphamide than those receiving carboplatin-paclitaxel. However, further research with a larger sample is still needed. Gastrointestinal side effects are more frequent in patients getting cisplatin-cyclophosphamide, while peripheral sensory neuropathy and hematologic side effects are found more frequently in patients getting carboplatinpaclitaxel chemotherapy.

\section{REFERENCES}

1. International Agency for Research on Cancer. GLOBOCAN 2012: Estimated cancer incidence, mortality and prevalence worldwide in 2012 [Online]. 2012 [cited in 2012]. Available from: URL:http://globocan.iarc.fr/

2. Siegel R, Naishadham D, Jemal A. Cancer Statistics, 2012. CA Cancer J Clin 2012; 62(1): 10-29.

3. Busmar B. Kanker ovarium. In: Syarifudin, editor. Buku acuan nasional. Jakarta: Yayasan Bina Pustaka; 2006: 468527.

4. Berek J. Epithelial ovarian cancer. In: Berek JS, Hacker NF. (eds). Practical gynecologic oncology. Philadelphia: Lippincott Williams and Wilkins; 2005: 443-509.

5. Nagell JR. Ovarian cancer: etiology, screening, and surgery. In: Rock JA, Jones HW. (eds). Te Linde's operative gynecology. Philadelphia: Lippincott Williams and Wilkins; 2008: 1308-34.

6. Mutch D. The new FIGO staging system for cancers of the vulva, cervix, endometrium and sarcomas. Gynecol Oncol 2009; 115: 325-8.

7. Indonesian Society of Gynecologic Oncology (INASGO). Cancer Registry 2013 [Online]. 2013 [cited 2013]. Available from: URL: http://www.inasgo.com/webrscm/Laporan/ Data_pertahun 
8. McGuire WP, Hoskins WJ, Brady MF, et al. Cyclophosphamide and cisplatin compared with paclitaxel and cisplatin in patients with stage III and stage IV ovarian cancer. New Eng J Med 1996; 224(1): 1-6.

9. HOGI. Pedoman Pelayanan Kanker Ginekologi. $2^{\text {nd }}$ ed. Jakarta: Badan Penerbit FKUI; 2011.
10. Piccart MJ, Bertelsen K, James K, et al. Randomized intergroup trial of cisplatin-paclitaxel versus cisplatin-cyclophosphamide in women with advanced epithelial ovarian cancer: three-year results. J Nat Cancer Inst 2000; 92(9): 699-708.

11. Ries LA. Ovarian cancer: survival and treatment differences by age. Cancer 1993; 71(2 Suppl): 524-9 